\title{
Investigating the Policy of International Trading Companies of Iran in Using Letters of Credit
}

\author{
Atefe Ghasemi ${ }^{1,2}$, Azita Mallahi ${ }^{3}$, Hadiseh Sadeghi ${ }^{3}$ \& Mohammad Reza Hatamiasdabadi ${ }^{3}$ \\ ${ }^{1}$ Young Researchers and Elite Club, Damghan Branch, Islamic Azad University, Damghan, Iran \\ ${ }^{2}$ Faculty of Entrepreneurship, University of Tehran, Tehran, Iran \\ ${ }^{3}$ Faculty of Law, Damghan Branch, Islamic Azad University, Damghan, Iran \\ Correspondence: Atefe Ghasemi, Young Researchers and Elite Club, Damghan Branch, Islamic Azad University, \\ Damghan, Iran. Tel: 98-91-2498-9659. E-mail: atefeghasemi100@gmail.com
}

Received: March 8, 2016

Accepted: April 22, 2016 Online Published: May 29, 2016

doi:10.5539/jpl.v9n4p58

URL: http://dx.doi.org/10.5539/jpl.v9n4p58

\begin{abstract}
Letters of credit play a crucial role in international trade. In this study, we investigate the most preferable characteristics of letters of credit for the international trading companies in Iran. We seek to investigate which kind of guarantee (commercial L/C or standby L/C) they prefer to secure the performance of their client's obligations. Studied companies were 20 international trading companies in Tehran, from which 50 experts were participated in our survey study. For measuring the participants and their policy in using letters of credit, a questionnaire in Persian was designed. For analyzing data we used statistical tests (One-sample t-test). Data showed that being a guarantee, integration, documentary conditions, and secondary payment mechanism are four important reasons for international trading companies in Iran to use letters of credit in their contracts. Statistical results showed that "being a guaranteed credit" is the most important factor with a mean of $3.660 \pm$ 1.135.Also, we found significant relationship between these four factors and the $\mathrm{L} / \mathrm{C}$ usage policy $(\mathrm{p}<0.01$, and $\mathrm{p}<0.05$ ). We concluded that they mostly prefer standby letters of credit for securing their transactions.
\end{abstract}

Keywords: letters of credit, standby L/C, commercial L/C, trading companies, international law

\section{Introduction}

The use of the letters of credit as a tool to reduce risk has grown substantially over the past decade. Letters of credit also referred as documentary credits, accomplish their purpose by substituting the credit of the bank for that of the customer, for the purpose of facilitating trade. "A letter of credit (L/C) is a financial instrument issued by a bank or other intermediary which guarantees payment to a third party. The bank is referred to as the issuer. The bank's customer is referred to as the account party and the third party is the beneficiary. In effect, the letter of credit substitutes the bank's credit for its customer's credit so that the risk to the seller is virtually eliminated" (Mooney \& Blodgett, 1995). Letters of credit are usually negotiable. The issuing bank is obligated to pay not only the beneficiary, but also any bank nominated by the beneficiary. Negotiable instruments are passed freely from one party to another almost in the same way as money. To be negotiable, the letter of credit must include an unconditional promise to pay, on demand or at a definite time. The nominated bank becomes a holder in due course. As a holder in due course, the holder takes the letter of credit for value, in good faith, without notice of any claims against it. A holder in due course is treated favourably under the Uniform Commercial Code (UCC). The UCC defines a letter of credit as "an engagement by a bank or other person made at the request of a customer that the issuer will honor drafts or other demands for payment upon compliance with the conditions specified in the letter of credit".

There are basically two types of L/C: commercial and standby. The commercial letter of credit (CLC) is the primary payment mechanism for a transaction, whereas the standby letter of credit (SLC) is a secondary payment mechanism. What introduces SLC as an alternative instrument for CLC is that it is an eclectic technique which makes letters of credit and bank guarantees similar to each other by necessary presenting of the relevant documents when the obligator fails to perform his obligation. In other words, two basic characteristics of SLC, i.e. being documentary and serving as a guarantee cause it to be both a kind of letter of credit and similar to bank 
guarantee (McGuinness, 1995). Contracting parties do not usually expect the SLC to be used when it is necessary; they consider it as a supporting and alternative tool that is ready for use (Hinkelman, 2003).

Due to the importance of letters of credit in international trade law, some investigations have been conducted. For example, Mooney \& Blodgett (1995) studied commercial letters of credit in the global economy and its potential implications, and examined changes in both generally accepted accounting principles and in the courts' interpretation of the Uniform Commercial Code. Hahn (2007) investigated the governing laws on letters of credit under the UCC to provide the in-depth analysis with respect to how the choice of law matters for disputes arising out of letters of credit. Hao \& Xiao (2013) analysed the two principles of 'Independence' and 'Strict Compliance" related to letters of credit, and studied the risks exit in letter-of-credit transaction. Lahsasna (2013) looked at L/C from the viewpoint of the Shariah to formulate letters of credit based on principles of Islamic trade and finance. He stated that "the introduction of Islamic concepts into and the modification of letters of credit to meet the requirements of the Islamic trade and finance will enhance the efficacy of letters of credit and strengthen it's position in international trade". Considering above mentioned materials, in this study our purpose is to investigate the importance of letters of credit for the international trading companies In Iran. First we discuss the principles of letters of credit and their connected factors. Then, we review SLC and CLC and their common procedures. In section 3 we have provided the results of our study.

\section{Literature review}

\subsection{Principles of Letters of Credit}

Letters of credit are based on two principles: autonomy, and doctrine of strict compliance.

\subsubsection{The Autonomy of the Letter of Credit}

According to this principle, the $\mathrm{L} / \mathrm{C}$ is disassociated from the actual sales and other contracts and, thus, is not affected by any problems and disputes related to the contracts or dissatisfactions between the exporter and buyer. The main and only agreement that is arranged between the exporter and the bank is the letter of credit. The buyer's protest about the export cannot suspend payment of the $\mathrm{L} / \mathrm{C}$. The only case where a bank may refuse payment is in case of fraud or forgery in the transaction, referred to as "fraud exception". (Articles 3 and 4 of UCP 500)

\subsubsection{The Doctrine of Strict Compliance}

According to this principle, the exporter must respect the written terms "to the letter" of the L/C. If any discrepancy or inconstancy occurs between the documents presented by the exporter and what is actually specified in the $\mathrm{L} / \mathrm{C}$, the bank can refuse payment. Therefore, with a $\mathrm{L} / \mathrm{C}$, the buyer has the protection of the bank strictly controlling the documents, and the seller has the protection of getting paid if all documents comply with the letter of credit. (Youssef, 1998)

\subsection{Connecting Factors in Letters of Credit}

The most common and relevant connecting factors are as following: (Hahn, 2007)

- Formation place: Generally, a contract is concluded where acceptance of an offer becomes effective, but since national laws have different approaches to determine such a place, different places can be nominated as the place of formation of the contract depending on the rules of the applicable national law.

- Place of payment: the place of the payment is deemed to have a strong connection in determining the governing law of the contract. In a L/C, payments are made differently in the course of the transaction, e.g. by correspondent bank or the issuing bank.

- Language and currency: the language and currency used in the contract are important factors which indicate the choice of law in certain situations.

\subsection{Commercial and Standby Letters of Credit}

CLCs have been used for centuries to facilitate payment in international trade. It is a contractual agreement between a bank, known as the issuing bank, on behalf of one of its customers, authorizing another bank, known as the advising or confirming bank, to make payment to the beneficiary. The issuing bank, on the request of its customer, opens the letter of credit. The issuing bank makes a commitment to honor drawings made under the credit. The beneficiary is normally the provider of goods and/or services. Essentially, the issuing bank replaces the bank's customer as the payor. Majority of CLCs are issued subject to Uniform Customs and Practice for Documentary Credits (UCP). SLC has a different function than the CLC. A bank will issue a SLC on behalf of a customer to provide assurances of his ability to perform under the terms of a contract between the beneficiaries. 
The parties involved with the transaction do not expect that the letter of credit will ever be drawn upon. SLC can be issued subject to either the UCP or the International Standby Practices (ISP).

A standby letter of credit (SLC) is the bank's undertaking of fulfilling the applicant's obligations. It is issued as collateral and is therefore not intended to be used as a primary payment method like commercial letters of credit. Standby letters of credit will be liquefied only if the applicant defaults of its responsibilities under the underlying contract. SLC is a mixture of commercial letter of credit (CLC) and demand guarantee. SLC has the same structure as CLC whereas their role is almost the same as demand guarantees. According to ISP 98, "A standby is an irrevocable, independent, documentary, and binding undertaking when issued and need not so state". These are also the main characteristics of the CLC. The role of a SLC is that the issuer will "stand by" to perform in the event of the account party's non - performance or default.

Although the SLC and CLC may be similar in format, and treated alike by the UCC, the expectations of the parties involved are exactly opposite: "with a commercial letter of credit, if the underlying transaction goes through, payment is made on the letter of credit. In contrast, with a standby letter of credit, if the underlying transaction does not go through, payment is made on the letter of credit". (Banks, 1984)

\subsection{Procedures for Using CLC and SLC}

The following procedures include a flow of events that follow the decision to use a CLC. Procedures required to execute a SLC are less rigorous. SLC is a domestic transaction. It does not require a correspondent bank. The documentation requirements are also less tedious. The step-by-step process is as follows:

(1). Buyer and seller agree to conduct business. The seller wants a letter of credit to guarantee payment.

(2). Buyer applies to his bank for a letter of credit in favor of the seller.

(3). Buyer's bank approves the credit risk of the buyer, issues and forwards the credit to its correspondent bank (advising or confirming). The correspondent bank is usually located in the same geographical location as the seller (beneficiary).

(4). Advising bank will authenticate the credit and forward the original credit to the seller (beneficiary).

(5). Seller (beneficiary) ships the goods, then verifies and develops the documentary requirements to support the letter of credit. Documentary requirements may vary greatly depending on the perceived risk involved in dealing with a particular company.

(6). Seller presents the required documents to the advising or confirming bank to be processed for payment.

(7). Advising or confirming bank examines the documents for compliance with the terms and conditions of the letter of credit.

(8). If the documents are correct, the advising or confirming bank will claim the funds by:

- $\quad$ Debiting the account of the issuing bank;

- Waiting until the issuing bank remits, after receiving the documents;

- $\quad$ Reimburse on another bank as required in the credit.

(9). Advising or confirming bank will forward the documents to the issuing bank.

(10). Issuing bank will examine the documents for compliance. If they are in order, the issuing bank will debit the buyer's account.

(11). Issuing bank then forwards the documents to the buyer.

Figure 1 depicts these steps to the documentary credit. 


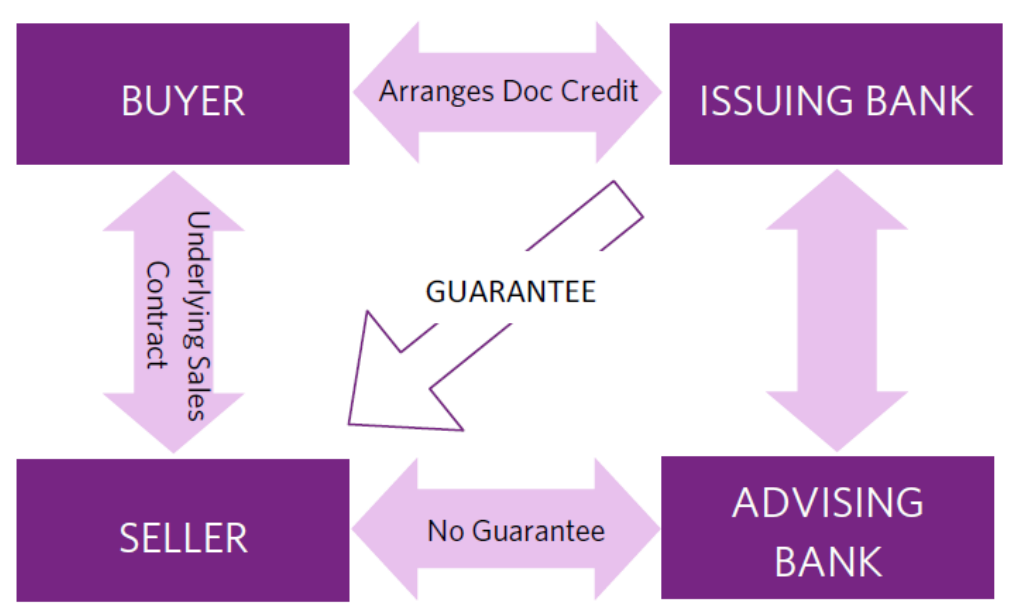

Figure 1. Steps and parties to the documentary credit

\section{Materials and Methods}

This study is a descriptive survey conducted according to The Uniform Customs and Practice for Documentary Credits (UCP) 500 guidelines. The statistical population is consisted of international trading companies in Tehran, Iran $(n=20)$. From these companies, 50 international trade experts were selected as the study sample using random sampling method. Data collection tool is a researcher-made questionnaire with acceptable validity and reliability which has 20 items scored based on 5-point likert scale concerning most preferred characteristics of letters of credit ranged from 1- very low to 5-very high. After distributing questionnaires among participants and collecting data, the indicators with high value were selected as the research measures. In this regard, four factors of "being guaranteed credit", "integration between CLC and SLC", "documentary conditions", and "being a secondary payment tool" were considered as independent variables and "preference of international trading companies in using letters of credit" was dependent variable. In this regard, we formulated our hypotheses as following:

- Hypothesis 1: Being a guaranteed credit can affect the preference of international trading companies in using letters of credit.

- Hypothesis 2: Integration between CLC and SLC has a relationship with the preference of international trading companies in using letters of credit.

- Hypothesis 3: Documentary condition is an effective factor in using letters of credit by international trading companies in Iran

- Hypothesis 4: Being a secondary payment tool affects the preference of International trading companies in Iran

Collected data were analyzed in SPSS software using statistical tests (one-sample $t$ test, bivariate regression test).

\section{Results and Discussion}

\subsection{Demographic Characteristics of Participants}

Results showed that most of participants in our study had ages between 45 and 55 with 15-20 years of work experience (see table 1) 
Table 1. Demographic characteristics

\begin{tabular}{ccc}
\hline Measure & Frequency & Frequency percent (\%) \\
\hline Age group & & \\
$35-45$ & 11 & 22 \\
$45-55$ & 25 & 50 \\
$>55$ & 14 & 28 \\
Total & 50 & 100 \\
\hline Work experience (year) & & \\
$10-15$ & 9 & 18 \\
$15-20$ & 23 & 46 \\
$20-25$ & 15 & 30 \\
$>25$ & 3 & 6 \\
Total & 50 & 100
\end{tabular}

\subsection{Statistics of Research Variables}

We investigated the opinion of participants about their preferred characteristics of $\mathrm{L} / \mathrm{C}$ which are listed in table 2. Results showed that "being a guaranteed credit" had highest importance among 4 studied factors with mean value and standard deviation of $3.660 \pm 1.135$.

Table 2. Statistics of study variables

\begin{tabular}{ccc}
\hline Variables & Mean & SD \\
\hline Being a guaranteed credit & 3.620 & 1.259 \\
Integration between CLC and SLC & 3.340 & 1.188 \\
Documentary conditions & 3.520 & 1.313 \\
Being a secondary payment tool & 3.660 & 1.135 \\
\hline
\end{tabular}

\subsection{Testing Research Hypotheses}

Before testing our hypotheses first we use Kolmogorov-Smirnov test to investigate the normality of data distribution; if the significant level be higher than error level $(\alpha=0.05)$, in this case, data have been normally distributed, otherwise the distribution is not normalized. Results of normality are presented in table 3 . As can be seen, Kolmogorov-Smirnov statistic is higher than 0.05; therefore, data has normal distribution so we can use parametric tests to examine our research hypotheses.

Table 3. Normality test results

\begin{tabular}{cccccc}
\hline Variables & K-S & Sample size & Sig. & P-value & Result \\
\hline Being a guaranteed letter of credit & 1.296 & 50 & 0.069 & 0.05 & Normal \\
Integration between CLC and SLC & 1.220 & 50 & 0.102 & 0.05 & Normal \\
Documentary conditions & 1.345 & 50 & 0.054 & 0.05 & Normal \\
Being a secondary payment tool & 1.279 & 50 & 0.076 & 0.05 & Normal \\
\hline
\end{tabular}

Hypothesis 1: For testing first hypothesis, we used one-sample t test. Results are shown in table 4. According to $\mathrm{t}$-statistics value which is 3.480 and $\mathrm{p}$-value $<0.05$, the relationship between two variables is significant at $99 \%$ confidence level. So, we can conclude that a guaranteed credit can affect the preference of international trading companies in Iran for using letters of credit. It can be stated that they prefer to use standby L/C. 
Table 4. One-sample t-test results for $\mathrm{H} 1$

\begin{tabular}{cccccc}
\hline \multicolumn{1}{c}{ Constant $=\mathbf{3}$} & & \\
\hline Model & Variables & t-statistics & $\begin{array}{c}\text { Degree of } \\
\text { freedom }\end{array}$ & p-value & $\begin{array}{c}\text { Mean } \\
\text { difference }\end{array}$ \\
\hline 1 & Being a guaranteed credit; preference & 3.480 & 49 & 0.001 & 0.620 \\
\hline
\end{tabular}

Hypothesis 2: According to table 5, $\mathrm{t}=2.029$ and $\mathrm{p}$-value $<0.05$; it can be said that the relationship between the two variables is significant at $95 \%$ confidence level. So, creating integrity between the letters of credit is efficient in increasing the preference of the international trading economies in using letters of credit for their transactions.

Table 5. One-sample t-test results for $\mathrm{H} 2$

\begin{tabular}{cccccc}
\hline \multicolumn{1}{c}{ Constant $=\mathbf{3}$} & & & \\
\hline Model & Variables & t-statistics & $\begin{array}{c}\text { Degree of } \\
\text { freedom }\end{array}$ & p-value & $\begin{array}{c}\text { Mean } \\
\text { difference }\end{array}$ \\
\hline 2 & Integration between CLC and SLC; preference & 2.029 & 49 & 0.049 & 0.340 \\
\hline
\end{tabular}

Hypothesis 3: Based on table 6, considering the t-statistics value (2.80) and p-value $<0.01$, the relationship between the two variables is significant in $99 \%$ confidence level. So documentary condition is an important factor for international trading companies in Iran; therefore we can say that they prefer documentary credits or $\mathrm{L} / \mathrm{Cs}$.

Table 6. One-sample t-test results for $\mathrm{H3}$

\begin{tabular}{cccccc}
\hline \multicolumn{7}{c}{ Constant $=\mathbf{3}$} \\
\hline Model & Variables & t-statistics & Degree of freedom & p-value & Mean difference \\
\hline 3 & Documentary conditions; preference & 2.80 & 49 & 0.007 & 0.520 \\
\hline
\end{tabular}

Hypothesis 4: In table 7 , as can be seen, $\mathrm{t}=4.10$ and $\mathrm{p}$-value $=0.000<0.01$; so the relationship between two variables is significant at $99 \%$ confidence level. So, we can say that international trading companies in Iran prefer to also have a secondary payment tool for their transactions. For this reason, SLCs are also used by them.

Table 7. One-sample t-test results for $\mathrm{H} 4$

\begin{tabular}{cccccc}
\hline \multicolumn{1}{c}{ Constant=3 } & & & \\
\hline Model & Variables & t-statistics & $\begin{array}{c}\text { Degree of } \\
\text { freedom }\end{array}$ & p-value & $\begin{array}{c}\text { Mean } \\
\text { difference }\end{array}$ \\
\hline 3 & Being a secondary payment tool; preference & 4.10 & 49 & 0.000 & 0.660 \\
\hline
\end{tabular}

\section{Conclusion}

Our purpose in this paper was to investigate the importance of letters of credit (CLC and SLC) for international trading companies in Iran. For this reason we surveyed 50 International trade experts in Iran about their preferred factors in using letters of credit. Descriptive findings showed that being a guarantee, integration, documentary conditions, and secondary payment mechanism are four important factors for international trading companies in Iran. Next, we created four hypotheses and then examined them by statistical tests in SPSS software. Our results revealed that documentary credits are frequently used by the companies. Also according to participants, we found that they mostly prefer standby letter of credit for their transaction. 


\section{References}

Banks, J. L. (1984). The Standby Letter of Credit: What It Is and How To Use It. Montana Law Review, 45, 1-10.

Hahn, J. (2007). Governing Laws on Letters of Credit under Uniform Commercial Code. Journal of Korea Trade, $11,115-134$.

Hao, Y., \& Xiao, L. (2013). Risk Analysis of Letter of Credit Based on Principles of Independence and Strict Compliance. International Journal of Business and Social Science, 4, 199-209.

Hinkelman, E. G. (2003). A Short Course in International Payments. California: World Trade Press,

Lahsasna, A. (2013). Implementation of the Islamic Letter of Credit in International Trade. Malaysia: Islamic Science University of Malaysia (USIM). Retrieved from http://www.ilovetheuae.com/uploads/credit.pdf

McGuinness, K. P. (1995). The Law of Guarantee (2nd ed). Scarborough: Carswell.

Moone, J. L., \& Blodgett, M. S. (1995). Letters of Credit in the Global Economy: Implications for International Trade. Journal of International Accounting Auditing \& Taxation, 4, 175-183. http://dx.doi.org/10.1016/1061-9518(95)90016-0

Youssef, F. (1998). Documentary risk in commodity trade. Geneva: UNCTAD.

\section{Copyrights}

Copyright for this article is retained by the author(s), with first publication rights granted to the journal.

This is an open-access article distributed under the terms and conditions of the Creative Commons Attribution license (http://creativecommons.org/licenses/by/3.0/). 